
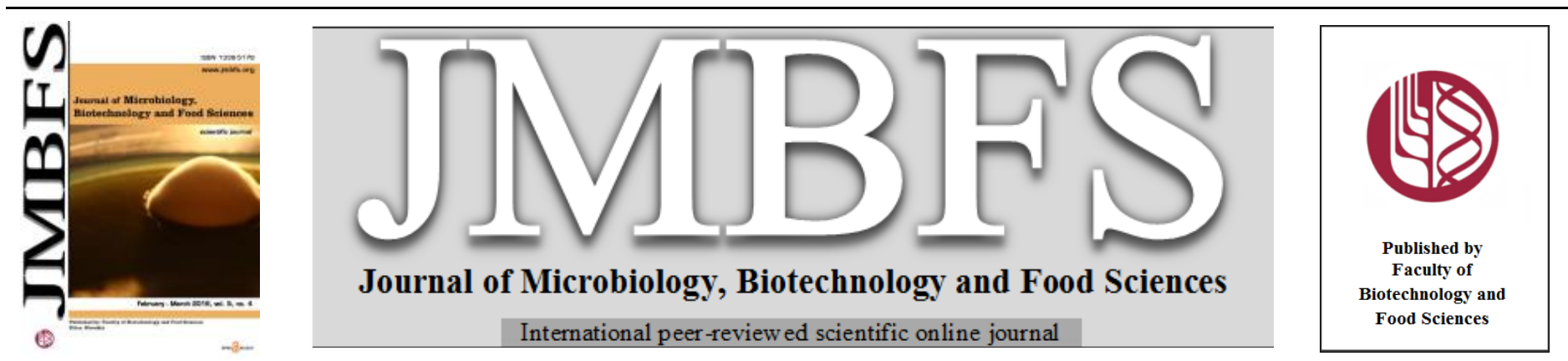

\title{
STUDIES ON THE OCCURRENCE OF COXIELLA BURNETII INFECTION IN TICKS IN SELECTED EASTERN AND CENTRAL REGIONS OF POLAND
}

\section{Agata Bielawska-Drózd ${ }^{*}{ }^{1}$, Piotr Cieślik ${ }^{1}$, Bożena Wlizto-Skowronek ${ }^{1}$, Przemysław Zięba ${ }^{2}$, Grzegorz Pitucha ${ }^{3}$ Jerzy Gawel ${ }^{1}$, Józef Knap $^{4}$}

\author{
Address(es): dr Agata Bielawska-Drózd, \\ ${ }^{1}$ Military Institute of Hygiene and Epidemiology, Biological Threats Identification and Countermeasure Centre, Lubelska 2 St., $24-100$ Puławy, Poland. \\ ${ }^{2}$ State Veterinary Laboratory, Słowicza 2 St., 20-336 Lublin, Poland. \\ ${ }^{3}$ University of Rzeszów, Department of Zoology, Zelwerowicza 4 St., 35-601 Rzeszów, Poland. \\ ${ }^{4}$ Warsaw Medical University, Second Faculty of Medicine, Department of Epidemiology, Oczki 3 St., 02-007 Warsaw, Poland.
}

*Corresponding author: abielawska@wihe.pulawy.p1

doi: 10.15414/jmbfs.2016.5.4.355-357

\section{ARTICLE INFO}

Received 1. 12. 2014

Revised 31. 3. 2015

Accepted 12. 11. 2015

Published 1. 2. 2016

\section{$\underline{\text { Regular article }}$}

open 2 access

\begin{abstract}
Arthropods may play a role in the transmission of Coxiella burnetii as they transmit pathogen both mechanically (as flies), and actively during the host blood suction. The aim of this study was to identify the $C$. burnetii occurring in ticks harvested from both domestic and livestock animals, as well as from wildlife in randomly selected regions of Poland. The total number 1126 ticks was collected in four regions of Poland: the Masovian, Lublin, Łódź and Podkarpackie Provinces. Among ticks collected from May 2011 to August 2012 , the presence of IS1111 gene sequence was detected in $15(1.33 \%)$ cases by real-time PCR test. Among the ticks harvested from domestic and livestock animals in 12 cases $(3.1 \%)$, and in case of ticks found in open-space rodents in 3 cases $(0.4 \%)$ we found the presence of marker sequences. The low percentage of $C$. burnetii infected ticks indicate a limited role of these arthropods in $\mathrm{Q}$ fever transmission.
\end{abstract}

Keywords: Coxiella burnetii, ticks, IS1111, real-time PCR

\section{INTRODUCTION}

In humans, the most frequent routes of infection are via inhalation (Dutkiewicz et al., 2011), direct contact of pathogen with damaged skin and mucous membrane, via the alimentary tract, and as a result of contact with $C$. burnetii infected ticks. In the latter case the infection can be transmitted during, the tick blood suction as well as by contact with its excrements. In the Dermacentor andersoni faeces the bacteria survive even up to 580 days (Woldehiwet, 2004). The reservoir of $C$. burnetii comprises a wide range of species, including all vertebrates, as well as parasitic invertebrate animals. Reported data described cases of $C$. burnetii isolation from samples of animals such as sheep, goats, cattle, dogs, cats and many species of wild-living vertebrates, including bears, bison, deer, boars, rabbits, hares, shrews and marsupials. Arthropods may play a significant role in pathogen transmission, as they transmit $C$. burnetii both mechanically (e.g. flies), and actively during the host blood suction, the host may be also infected through the cutaneous or inhalation contact with the parasites faeces (Marrie, 1990; Anusz, 1995). The role of ticks in spreading the pathogen results from theirs manner of feeding and the ability of transstadial transmission. The ability of pathogen transmission (including transovarial) has been reported in about 40 ticks species (Mediannikov et al., 2010). Since ticks can reside on at least two to three different hosts (mainly mammals) during their life-cycle, they are considered as one of the factors determining the persistence of $C$. burnetii in the environment (Fard and Khalili, 2011). The infection of ticks by C. burnetii occurs during the blood sucking of on infected mammal or other vertebrate, whereby they become a vector of this microorganism (Norlander, 2000; Bossi $\boldsymbol{e t}$ al., 2004; Hartzell et al., 2008; Oyston and Davies, 2011).

The aim of this study was to identify the $C$. burnetii occurring in ticks harvested from both domestic and livestock animals, as well as wildlife in randomly selected regions of Poland.

\section{MATERIALS AND METHODS}

\section{Ticks collection}

Ticks were collected in four regions of Poland: the Masovian Province (central region of Poland) - 27 Ixodes ricinus: 5 from wildlife (deer, boar), 2 from domestic animals (cats, dogs), 20 from cattle; 4 Dermacentor reticulatus from domestic animals, Lublin Province (eastern Poland) - 95 I. ricinus: 57 from wildlife, 18 from open-space rodents, 8 from cattle, 12 from domestic animals, 2 D. reticulatus from domestic animals, 16 Ixodes hexagonus from domestic animals, Łodź Province (central Poland) - 18 I. ricinus from domestic animals; 2 I. hexagonus from domestic animals, and Podkarpackie Province (south-eastern Poland, mountains and sub-mountains region) - 699 I. ricinus: 325 from wildlife, 75 from open-space rodents, 62 from domestic animals, 184 from cattle, 53 from goats; $5 \mathrm{I}$. persulcatus from wildlife; 257 D. reticulatus from wildlife; 1 Dermacentor marginatus from wildlife.

The specimens were collected from May 2011 to August 2012. A total of 1126 ticks were collected, representing the following species: I. ricinus $(74.5 \%), D$. reticulatus $(23.3 \%)$, I. persulcatus $(0.45 \%)$, I. hexagonus $(1.66 \%)$ and $D$. marginatus $(0.09 \%)$.

Ticks were removed directly from animals, 743 specimens were taken from wild animals and another 383 ticks were harvested from domestic and livestock animals.

Among the $I$. ricinus species 839 mature individuals were collected, including 707 females feeding, 120 males and 12 nymphs. From the D. reticulatus species 117 adult females and 146 males were caught, and also 5 females from the species $I$. persulcatus, 17 adult females and one nymph from the $I$. hexagonus species, and from the D. marginatus species - one adult female. Ticks were placed in sterile $2 \mathrm{ml}$ tubes and stored at $-20^{\circ} \mathrm{C}$ until further analysis.

\section{Ticks identification and treatment, Genetic material isolation}

Identification of tick species was carried out according to the identification key (Siuda, 1993) using a dissecting microscope at magnification range $3.5-90 \times$ in the reflected artificial light, and with regard to the larvae in transmitted light. For tick treatment, the modified method described by Mediannikov et al. (2010) was implemented. In order to eliminate the possible microbiological contamination including Bacillus cereus group, ticks were treated with $0.5 \%$ solution of sodium hypochlorite for 10 minutes. In the next stage, the ticks were rinsed with distilled water, dried and re-suspended in $70 \%$ ethanol for 10 minutes. Finally, the samples were rinsed with distilled water and PBS. Remains of the fluids were then removed and dry ticks were re-suspended in $0.6 \mathrm{ml}$ of MEM (Minimum Essential Medium, Sigma-Aldrich, USA) without antibiotic and homogenized by Stuart ${ }^{\circledR}$ SHM-1 apparatus. The homogenate was filled up to $2 \mathrm{ml}$ 
with MEM. Chitin remains were precipitated and liquid layer $(1 \mathrm{ml})$ was centrifuged at $25000 \times \mathrm{g}$, the pellet was re-suspended in MEM $(5 \mathrm{ml})$ and then twice filtered through $0.45 \mu \mathrm{m}$ membrane. The filtrate was used for infection the BGM cell line (African monkey green kidney, HPA Culture Collection, UK) (Mediannikov et al., 2010). Bacterial DNA was isolated from $1 \mathrm{ml}$ of the suspension obtained after homogenization of the ticks, using Genomic AX Tissue Mini Spin Kit (A\&A Biotechnology, Gdynia, Poland) according to manufacturer's recommendations.

\section{Real-time PCR}

Real-time PCR method was used for detecting the presence of insertion sequence IS1111 (transposase gene, GenBank: M80806) (Klee et al., 2006) using the following primers and probe sequence: IS1111F: 5'GTCTTAAGGTGGGCTGCGTG-3', IS1111R: CCCCGAATCTCATTGATCAGC-3', IS1111P: 5'- FAM AGCGAACCATTGGTATCGGACGTTT-TAMRA-TATGG-Pho-3'

The real-time PCR reaction was performed in a capillary system in the LightCycler 2.0 (Roche, Poland) in a final reaction volume of $20 \mu$ l. The reaction mixture consisted of the LightCycler TaqMan Master Kit (Roche, Germany) - 10 $\times$ conc., primers $-0.5 \mu \mathrm{M}$, probe $-0.15 \mu \mathrm{M}$ and $5 \mu$ of template DNA.

The reaction using hydrolyzing probes for $I S 1111$ gene sequence was carried out according to previously optimized thermal profile: $10 \mathrm{~min}$. at $95^{\circ} \mathrm{C}$ (initia denaturation), $15 \mathrm{~s}$ at $95^{\circ} \mathrm{C}, 30 \mathrm{~s}$ at $60^{\circ} \mathrm{C}(40$ cycles of amplification), $30 \mathrm{~s}$ at $40^{\circ} \mathrm{C}$.

As a positive control DNA extracted from $C$. burnetii strain Nine Mile phase I was used, and as a negative control a reaction mixture without template DNA was used. Real-time PCR was performed for 40 cycles, and the test samples for which $\mathrm{C}_{\mathrm{t}}$ (Cycle threshold) was lower than 36 were considered as positive. For samples for which the fluorescence signal was weak $\left(>36 \mathrm{C}_{\mathrm{T}}\right)$, additionally a second round of real - time PCR using the same set of primers and probes was performed.

\section{C. burnetii culturing}

Culturing of the BGM cell line was carried out in the presence of MEM culture medium containing: $2 \mathrm{mM}$ glutamine (Sigma-Aldrich, USA), $1 \%$ Non-essential amino acids (NEAA, (Sigma-Aldrich, USA)), 10\% FBS (Fetal bovine serum, Sigma-Aldrich, USA), $100 \mu \mathrm{g} / \mathrm{ml}$ streptomycin and $100 \mathrm{U} / \mathrm{ml}$ penicillin (SigmaAldrich, USA) at $37^{\circ} \mathrm{C}$ in the presence of $5 \% \mathrm{CO}_{2}$.

The filtrate obtained from homogenized ticks in the amount of $0.5 \mathrm{ml}$ was used for infection of the BGM cell line. Culturing of the infected cell line was carried out at $37^{\circ} \mathrm{C}$ in the presence of $5 \% \mathrm{CO}_{2}$. No antibiotics were added to culture medium. C. burnetii was then recovered from the cell line, in order to do that the method using digitonin described by Cockrell et al. (2008) was employed.

\section{RESULTS AND DISCUSSION}

From 1126 ticks harvested in the selected regions of Lublin, Podkarpackie, Masovian, and Łódź Provinces, the presence of C. burnetii-specific IS1111 gene sequence was found in $15(1.33 \%)$ cases (Tab. 1). Among the positive samples, five were acquired in Lublin Province ( $4-$ I. ricinus, $1-D$. reticulatus), seven in Masovian and Łodź Provinces $(6-I$. ricinus, $1-I$. hexagonus $)$ and three in Podkarpackie Province (I. ricinus). In case of seven tick samples, the $\mathrm{C}_{\mathrm{T}}$ fluorescence had the value of 31 , for the next two it was above 35 cycles, and for others the signal was detected in the second round of real-time PCR. Among ticks harvested from domestic and livestock animals in 12 cases (3.1\%), and in case of ticks found in open-space rodents in 3 cases $(0.4 \%)$ we found the presence of marker sequences.

Table 1 Summary of positive test results for the presence of $C$. burnetii infections in ticks

\begin{tabular}{|c|c|c|c|c|c|}
\hline No. & Province & Place/District & Animal species/ source & Tick species & Description \\
\hline 1. & \multirow{4}{*}{ Lublin } & \multirow{4}{*}{ Puławy } & Dog & I. ricinus & $\mathrm{A}, \mathrm{P}, \mathrm{F}$ \\
\hline 2. & & & Dog & I. ricinus & $\mathrm{A}, \mathrm{P}, \mathrm{F}$ \\
\hline 3. & & & Cat & I. ricinus & $\mathrm{A}, \mathrm{P}, \mathrm{F}$ \\
\hline 4. & & & Dog & I. ricinus & $\mathrm{A}, \mathrm{P}, \mathrm{F}$ \\
\hline 5. & Lublin & Ryki & Dog & D. reticulatus & $\mathrm{A}, \mathrm{G}, \mathrm{F}$ \\
\hline 6. & \multirow{4}{*}{ Masovian } & \multirow{4}{*}{ Pułtusk } & Cat & I. ricinus & $\mathrm{A}, \mathrm{P}, \mathrm{F}$ \\
\hline 7. & & & Dog & I. ricinus & $\mathrm{A}, \mathrm{P}, \mathrm{F}$ \\
\hline 8. & & & Dog & I. ricinus & $\mathrm{A}, \mathrm{P}, \mathrm{F}$ \\
\hline 9. & & & Dog & I. ricinus & $\mathrm{A}, \mathrm{P}, \mathrm{F}$ \\
\hline 10. & \multirow{3}{*}{ Łódź } & \multirow{3}{*}{ Łódź } & Cat & I. ricinus & $\mathrm{A}, \mathrm{P}, \mathrm{F}$ \\
\hline 11. & & & Dog & I. ricinus & $\mathrm{A}, \mathrm{P}, \mathrm{F}$ \\
\hline 12. & & & Dog & I. hexagonus & $\mathrm{A}, \mathrm{P}, \mathrm{F}$ \\
\hline 13. & \multirow{3}{*}{ Podkarpackie } & \multirow{3}{*}{ Sanok } & Open-space rodent ${ }^{1}$ & I. ricinus & $\mathrm{A}, \mathrm{P}, \mathrm{F}$ \\
\hline 14. & & & Open-space rodent ${ }^{1}$ & I. ricinus & $\mathrm{A}, \mathrm{P}, \mathrm{F}$ \\
\hline 15. & & & Open-space rodent ${ }^{2}$ & I. ricinus & $\mathrm{A}, \mathrm{G}, \mathrm{F}$ \\
\hline
\end{tabular}

${ }^{1}$ - Striped field mouse (Apodemus agrarius), ${ }^{2}$ - Common vole (Microtus arvalis), A - Adult individual, $\mathrm{P}$ - The individual was feeding, $\mathrm{G}-$ The individual was not feeding, $\mathrm{F}$ - Female

Additionally, the biological material isolated from ticks and cultured in BGM cell line gave positive results of amplification in two cases of I. ricinus: from Masovian and Lublin Provinces.

The surveillance among ticks is rarely conducted in Poland. The studies initiated by Anusz (1990) revealed C. burnetii in females I. ricinus (Warmian-Masurian Province, north-eastern Poland). Simultaneously Tylewska-Wierzbanowska $\boldsymbol{e t}$ al. (1996) revealed $3(0.19 \%)$ C. burnetii positive ticks, out of 1580 collected in various regions of Poland (former Bydgoszcz, Koszalin, Piła, Płock, Warszawa, Kielce and Tarnobrzeg Provinces). Contrarily, another group (Niemczuk et al., 2011) carried out studies between 2009 and 2010 on a limited number of ticks in Lublin Province and yielded $33.3 \%$ positive results of $C$. burnetii genetic material. Moreover, the same researchers between $2011-2013$ examined the $I$. ricinus collected from endemic area in south-eastern Poland. The percentage of ticks infected with C. burnetii was $15.9 \%$ (Szymańska-Czerwińska et al., 2013) Supposedly, such high percentage of positive results is related to sampling the specimens from natural focus of $\mathrm{Q}$ fever. Studies on the presence of $C$. burnetii among ticks from other parts of the world revealed rather low percentage of infected individuals (from 0.3\% to 7.7\%) (Mediannikov et al., 2010; Fard and
Khalili, 2011; Špitalská et al., 2003; Toledo et al., 2009; Hildebrandt et al., 2011; Sprong et al., 2012).

In our studies only two isolates were recovered from all 15 BGM cell line cultures. Due to intracellular type of $C$. burnetii infection, the method of bacteria recovery is crucial - significant losses of material may be sustained during the isolation procedure. The digitonin, which has high affinity to PV (parasitophorous vacuole, containing cholesterol) was successfully utilized in the present study. This intracellular structure is the place of $C$. burnetii proliferation. On the other hand, bacterial coinfections (such as Borrelia spp.), noted mainly among samples obtained from ticks, disturbed some cell cultures and impaired $C$. burnetii recovery from the cells. Sonication method, which is an alternative option for $C$. burnetii isolation, was not used due to accompanying risk related to unintentional generation of biological aerosol (Cockrell et al., 2008). We used multi-copy IS1111 gene (7 to 110 per one cell of C. burnetii), which is a very convenient and sensitive genetic marker as a tool for $C$. burnetii screening in ticks (Klee et al., 2006; Bielawska-Drózd et al., 2013).

Pathogen may be transmitted by number of ticks species, the castor bean tick ( $I$ ricinus) seems to be the most epidemiologically important species in Poland (Tylewska-Wierzbanowska et al., 1996; Bielawska-Drózd et al., 2013). Not 
only it is the most prevalent species, but also it has a significant range of hosts. This assumption was confirmed in the current study, showing that the most of infected ticks were I. ricinus. The meadow tick (D. reticulatus) may be taken into account as the second most predominant tick in the eastern Poland (TylewskaWierzbanowska and Chmielewski, 2010).

Currently, the role of ticks as vectors and reservoir of Q fever is disputable. Some researchers (Mediannikov et al., 2010; Tylewska-Wierzbanowska and Chmielewski, 2010; Sprong et al., 2012) claim that ticks, as vectors of $C$. burnetii do not play a significant role in disease transmission among animals and humans. Contrarily, Toledo et al. (2009) observed high number of infected individuals among $H$. lusitanicum and $D$. marginatus population, which support the hypothesis about their role in $\mathrm{Q}$ fever transmission. Also other authors claim that ornate sheep tick (D. marginatus) is the most significant vector of $C$. burneti in the middle Europe (Hildebrandt et al., 2011). Results of the current study demonstrated a low proportion of infected ticks (1.33\%), which may confirm the first thesis. Nonetheless, ticks may be an important factor in C. burnetii transmission among wild animals, such as rodents, lagomorphs or wild birds (Fard and Khalili, 2011; Astobiza et al., 2011).

\section{CONCLUSION}

In our research, a low percentage of $C$. burnetii infected ticks $(1.33 \%)$ indicated by the probe specific real-time PCR for multi-copy insertion sequence (IS1111), reveals limited role of these arthropods in $\mathrm{Q}$ fever transmission in Poland.

Acknowledgments: The study has been funded by the Ministry of Science and Higher Education of the Republic of Poland (Grant No. N N308 562540). Reference strains of C. burnetii (F4, Nine Mile, RT-1 and Z349-36/94) were kindly provided by Dr. Dimitrios Frangoulidis and Dr. Holger Scholz form Microbiology Institute of German Armed Forces (Munich, Germany).

We also would like to acknowledge laboratory technicians Barbara Ciecierska and Dorota Sikorska for the technical assistance in the samples preparation.

\section{REFERENCES}

Anusz, Z., Rehacek, J., Siemionek, J., Kovacova, E., Kocianova, E., Lisak, V., Platt-Samoraj, A., Urvolgyi, J. (1990). Present status of Q fever in Olsztyn province, Poland. In: Kazar J, Raoult D, (ed). Rickettsiae and rickettsial diseases. (Proccedings of 4th Int Symposium, Publishing House of the Slovak Academy of Sciences) Bratislava:1991 496-499.

Anusz, Z. (1995). Q fever in humans and animals. Olsztyn: ART.

Astobiza, I., Barral, M., Ruiz-Fons, F., Barandika, J. F., Gerrikagoitia, X., Hurtado, A., \& García-Pérez, A. L. (2011). Molecular investigation of the occurrence of Coxiella burnetii in wildlife and ticks in an endemic area $\begin{array}{lll}\text { Veterinary } & \text { Microbiology, } & \text { 147(1), }\end{array}$ http://dx.doi.org/10.1016/j.vetmic.2010.05.046

Bielawska-Drózd, A., Cieslik, P., Mirski, T., Bartoszcze, M., Knap, J. P., Gawel, J., \& Zakowska, D. (2013). Q fever-selected issues. Annals of Agricultural and Environmental Medicine, 20(2).

Bossi, P., Tegnell, A., Baka, A., Van Loock, F., Werner, A., \& Hendriks, J. (2004). Bichat guidelines for the clinical management of $Q$ fever and bioterrorism-related Q fever. Euro Surveill, 9(12), E19-E20.

Cockrell, D. C., Beare, P. A., Fischer, E. R., Howe, D., \& Heinzen, R. A. (2008) A method for purifying obligate intracellular Coxiella burnetii that employs digitonin lysis of host cells. Journal Of Microbiological Methods, 72(3), 321325. http://dx.doi.org/10.1016/j.mimet.2007.12.015

Dutkiewicz, J., Cisak, E., Sroka, J., Wójcik-Fatla, A., \& Zajac, V. (2011) Biological agents as occupational hazards-selected issues. Annals of Agricultural and Environmental Medicine, 18(2).

Fard, S. N., \& Khalili, M. (2011). PCR-detection of Coxiella burnetii in ticks collected from sheep and goats in southeast Iran. Iranian Journal Of ArthropodBorne Diseases, 5(1), 1.

Hartzell, J. D., Wood-Morris, R. N., Martinez, L. J., \& Trotta, R. F. (2008, May) $\mathrm{Q}$ fever: epidemiology, diagnosis, and treatment. In Mayo Clinic Proceedings (Vol. 83, No. 5, pp. 574-579). Elsevier. http://dx.doi.org/10.1016/S0025 6196(11)60733-7

Hildebrandt, A., Straube, E., Neubauer, H., \& Schmoock, G. (2011). Coxiella burnetii and coinfections in Ixodes ricinus ticks in central Germany. VectorBorne and Zoonotic Diseases, 11(8), 1205-1207.

Klee, S. R., Tyczka, J., Ellerbrok, H., Franz, T., Linke, S., Baljer, G., \& Appel, B. (2006). Highly sensitive real-time PCR for specific detection and quantification of Coxiella burnetii. BMC Microbiology, 6(1), 2.

Marrie, T.J. (1990). (Edit). Q fever - the disease. Boca Raton: CRC Press.

Mediannikov, O., Fenollar, F., Socolovschi, C., Diatta, G., Bassene, H., Molez, J. F., ... \& Raoult, D. (2010). Coxiella burnetii in humans and ticks in rural Senegal. PLoS Negl Trop Dis, 4(4), e654. http://dx.doi.org/10.1371/journal.pntd.0000654 Niemczuk, K., Szymańska-Czerwińska, M., Zarzecka, A., \& Konarska, H. (2011). Q fever in a cattle herd and humans in the south-eastern Poland Laboratory diagnosis of the disease using serological and molecular methods. Bull Vet Inst Pulawy, 55(4), 593-598.
Norlander, L. (2000). Q fever epidemiology and pathogenesis. Microbes And Infection, 2(4), 417-424. http://dx.doi.org/10.1016/S1286-4579(00)00325-7

Oyston, P. C., \& Davies, C. (2011). Q fever: the neglected biothreat agent Journal Of Medical Microbiology, 60(1), 9-21. http://dx.doi.org/10.1099/jmm.0.024778-0

Siuda, K. (1993). Kleszcze (Acari, Ixodida) Polski. Cz. 2, Systematyka rozmieszczenie. Monografie Parazytologiczne $\mathrm{Nr}$ 12. Warszawa: Polskie Towarzystwo Parazytologiczne, p. 381

Špitalská, E., \& Kocianova, E. (2003). Detection of Coxiella burnetii in ticks collected in Slovakia and Hungary. European Journal Of Epidemiology, 18(3), 263-266.

Sprong, H., Tijsse-Klasen, E., Langelaar, M., De Bruin, A., Fonville, M. Gassner, F., ... \& Van Duynhoven, Y. T. (2012). Prevalence of Coxiella burnetii in ticks after a large outbreak of Q fever. Zoonoses And Public Health, 59(1), 69 75. http://dx.doi.org/10.1111/j.1863-2378.2011.01421.x

Szymańska-Czerwińska, M., Galińska, E. M., Niemczuk, K., \& Zasępa, M. (2012). Prevalence of Coxiella burnetii infection in foresters and ticks in the south-eastern Poland and comparison of diagnostic methods. Annals Of Agricultural And Environmental Medicine, 20(4), 699-704.

Toledo, A., Jado, I., Olmeda, A. S., Casado-Nistal, M. A., Gil, H., Escudero, R., \& Anda, A. P. (2009). Detection of Coxiella burnetii in ticks collected from Central Spain. Vector-Borne and Zoonotic Diseases, 9(5), 465-468.

Tylewska-Wierzbanowska, S., Kruszewska, D., Chmielewski, T., Zukowski, K., \& Zabicka, J. (1995). Ticks as a reservoir of Borrelia burgdorferi and Coxiella burnetii on Polish terrain. Przeglad Epidemiologiczny, 50(3), 245-251.

Tylewska-Wierzbanowska, S., \& Chmielewski, T. (2010). Zoonozy przenoszone przez kleszcze na terenie Polski. Postępy Mikrobiologii, 3(49), 191-197.

Woldehiwet, Z. (2004). Q fever (coxiellosis): epidemiology and pathogenesis. $\begin{array}{llll}\text { Research In Veterinary } \quad \text { Science, } & 77(2), & 93-100\end{array}$ http://dx.doi.org/10.1016/j.rvsc.2003.09.001 